\title{
BLACK SOLDIER FLY LARVAE AS ANIMAL FEED: IMPLICATIONS ON THE HALAL STATUS OF MEAT PRODUCTS
}

\author{
MARYAM WAN KHAIRUZZAMAN ${ }^{1}$, MOHAMMAD AIZAT JAMALUDIN ${ }^{2 *}$, MUHAMAD \\ SHIRWAN ABDULLAH SANI ${ }^{3}$ \\ International Institute for Halal Research and Training (INHART), International Islamic University \\ Malaysia, Jalan Gombak, 53100 Kuala Lumpur, Malaysia. \\ *Corresponding author: mohdaizat@iium.edu.my
}

(Received: $11^{\text {th. }}$ Nov. 2020, Accepted: $30^{\text {th }}$ Dec. 2020, Published on-line: $15^{\text {th }}$ Jan. 2021)

\begin{abstract}
In the mid-twentieth century, research conducted found that black soldier fly (BSF) larvae caused the reduction of housefly breeding and manure accumulation in a chicken barn. As a result, the commercialisation of BSF larvae for agricultural use and biowaste treatment ensues. Facilities were built to produce BSF larvae on a large scale where rearing, processing, and harvesting occur. The larvae are fed with municipal and agro-industrial wastes and faeces. Feeding animals with BSF larvae became widely practised for the benefit of serving as a vital source of protein for animals. BSF larvae prove to be a precious commodity to the agricultural industry for its utility in waste treatment and animal feed. However, it presents a problem to halal food production due to the nature of the feed formulation that contains faeces; this raises concern over the halal (lawful) status of the animals fed with BSF larvae. Will the lawful status be compromised? Should the animals fed with this type of feed formulation be categorised as al-jallalah animal? In Southeast Asia, no Islamic institutions are issuing a fatwa (legally binding authoritative religious ruling) concerning this, except for the Indonesian Ulema Council (MUI), even so, it is severely insufficient as it was only mentioned briefly, the focal issue was human consumption of BSF larvae not its use in feed formulation. The lack of discussion and research on this issue in Islamic and academic scholarship despite its ubiquity in food production and consumption demonstrates the necessity to invest more in research and enhance coordination between the jurisprudence and technical fields.
\end{abstract}

KEYWORDS: Animal feed; Black soldier fly; Halal ruling; Al-jallalah; Food Production

\section{INTRODUCTION}

The assurance of halal integrity along the food supply chain from farm to fork is a complicated task, one of the significant undertakings overlooked by many. To guarantee both halalan and toyyiban (lawful and wholesome), integrity is even more so. While the parameters of what is halal (lawful) and haram (unlawful) about food is relatively well-defined, toyyib, on the other hand, has far-reaching consequences as it covers all facets of sustainability including physical, environmental, social, economic and ethical footprints of a particular food (Iqbal, 
2015). To ensure food products embody both halalan and toyyiban concepts, Malaysia's poultry industry has been placed under scrutiny at every stage of the food supply chain. Omar et al. (2013) identified the third Halalan Toyyiban Critical Control Points (HTCCP) of the poultry supply chain, 'the type and quality of food being fed to the animal are important to determine the quality of the poultry as well as ensuring the products are halalan-toyyiban'. Therefore, animal feed must be ascertained of its origin, components, method of processing and other areas of concern to ensure it is halal and free from contaminants of haram origins.

\subsection{Black Soldier Fly (BSF) Larvae as Animal Feed in Poultry Farms and Aquaculture}

The poultry and aquaculture industry prefer animal-protein feed over plant-protein 'because animal proteins contain a good balance of essential amino acids and an excellent content of vitamins source for poultry and fish', (Saima et al., 2008). Insects are natural food sources for poultry. In Malaysia, the poultry and aquaculture industry mainly rely on BSF larvae (Hermetia illucens), among other insects, as animal feed because it is found in abundance in Malaysia, (Al-Qazzaz et al., 2016). The BSF is not considered as a pest, (Barragan-Fonseca et al., 2017). The adult BSF only consume water, does not approach humans, nor bite nor sting, and very unlikely to spread any specific diseases, (Wang \& Shelomi, 2017). Also, BSF has been reported to reduce pathogenic bacteria, including Escherichia coli and Salmonella enteritidis since the isolated bacteria from BSF's gut acts as prebiotic, (Barragan-Fonseca et al., 2017).

The BSF larva is a precious commodity because it boasts attractive attributes to poultry and aquaculture businesses looking to maximise profit wherever possible. BSF larvae can be composting agents and live bait, but they are primarily marketed as animal feed and commonly used in biowaste treatment and management. The BSF is favoured above all other insects due to the overall improvement in quality; it contributes to the end-product of aquaculture and poultry. Al-Qazzaz et al. (2016) found that there was a significant improvement in hen day egg production and hen house egg production due to dietary treatments of BSF larva, in addition to the improved appearance, texture, taste, and acceptance of eggs of hens fed with BSF larva. Participants in another study conducted by researchers at the University of California Davis campus reported a more pronounced 'eggy' taste, presumably more flavourful, in the eggs of hens fed with BSF larvae than those with a regular food pellet, (Wood, 2017).

Although the BSF has been reported to improve the taste of poultry meat, BSF naturally contains high levels of saturated fatty acids (SFA), (Wang \& Shelomi, 2017) and very low in polyunsaturated fatty acids (PUFA), which indirectly affect the distribution of fatty acids in the poultry when BSF becomes the feed, (Barroso et al., 2017). The high ratio of SFA/PUFA, especially omega 6/omega 3 fatty acids is undesirable due to this ratio contribute to cardiovascular diseases in human, (Gómez Candela et al., 2011). However, this ratio can be changed via manipulating the diet, i.e. fish meal inclusion to increase the omega 3 fatty acids in the BSF, (Barroso et al., 2017). Also, BSF larvae could be the host of potentially harmful microorganisms that render bacterial and viral diseases when manure is served as the BSF's feed and accumulate heavy metal such as cadmium when they are bred in a heavy metal contaminated environment, (Čičková et al., 2015). Although BSF has proved to inhibit the growth of pathogenic bacteria, research has found that Providencia spp. retains in every stage of BSF life. This pathogenic bacteria's existence may lead to disease infection to poultry and human, (Barragan-Fonseca et al., 2017). Besides, the coexistence of Bacillus subtilis that facilitates the growth of BSF, (Wang \& Shelomi, 2017) renders bacteremia, endocarditis, pneumonia, and 
septicemia to human. Because of the health concerns associated with BSF larvae' use as animal feed, this study attempts to address the doubts (shubhah) one might have about the permissibility of such feed for animals in light of the Islamic jurisprudence discipline.

\subsection{Coprophagy and Al-Jallalah}

Hirakawa (2001) defined coprophagy literally as faeces-eating, 'where faeces could conceivably be of various kinds: faeces of other species or the conspecifics; those of other individuals (allocoprophagy) or its own (autocoprophagy)'. The BSF larva feeds on decaying organic matter and biowaste, including faecal matter. Dortsman et al. (2017) assert that, in nature, the female BSF will find organic waste in a sheltered place to lay its eggs, once it lays the eggs it dies soon after. After four days the eggs would have hatched, and the larvae would find its way to the organic waste nearby to feed on it for 14-16 days, this is the only stage in its life that the BSF will eat. This feasting stage is pupation, and it ends when a BSF emerges, and thus the cycle begins anew. Engineering the BSF life cycle enables mass production of the larvae for biowaste treatment and animal feed product. At the processing facility, the larvae are fed segregated biowaste consisting of commercial wastes, faeces and manure from poultry, pigs, humans and faecal sludge, (Dortsman et al., 2017). Therefore, the BSF is saprophagous as well as it is coprophagous.

Al-jallalah has a broader meaning to it than coprophagy, while the latter is only limited to the consumption of faeces, the former covers all types of impurities deemed such by the Quran and prophetic tradition, including blood, carcass, pigs, dogs, and faeces etc. Hamdan et al. (2017) divided the definition of al-jallalah into two as follows:

(i) Animals that consume unclean and dirty things as its leading food. If the animal eats very little amount of unclean and dirty things, it is not included under al-jallalah animals. Nonetheless, although its meat or milk is not spoiled, it is still counted as al-jallalah animals if it consumes unclean and dirty things as the primary food.

(ii) Such animals are categorised as al-jallalah animals are when changes in meat and milk constituents presence, either in terms of the smell, taste and colour. Even if the animal only ate a minimal amount of unclean and dirty things that caused changes in its meat and milk, it still belongs to al-jallalah animals. Al-Nawawi and al-Rafi'i held this opinion.

It is well established in hadith (words, actions and silent approval of Prophet Muhammad PBUH-peace and blessings be upon him (is an honorific salutation used after Prophet Mohammad's name is mentioned) commentary literature that Prophet Muhammad PBUH prohibited Muslims from eating al-jallalah. This is evident in the ahadith (sing. hadith) found in the Kutub al-Sittah (The Authentic Six), it is found that there are thirteen hadith mentioning the prohibition against al-jallalah, (Saidin et al., 2017). The prohibition includes consumption of its meat, drinking of its milk and riding of the al-jallalah animal for jihad (striving in the path of God). Sunan Abi Dawud has the most collection of hadith on al-jallalah among the Kutub alSittah. The prohibition of eating the animal which feeds on filth and drinking its milk is found in Kitab Al-At'imah (The Book of Foods) under the chapter 'The prohibition of eating al-jallalah and its milk', (Abu Dawud, 2009), another narration in the same chapter mentions the prohibition of riding it and eating its flesh. The hadith mentioning the prohibition of riding camels that eat dung and similar beasts is found in the Book of Jihad, (Abu Dawud, 2009). 
According to Iqbal et al. (2019), 'Al-Shafi'i proposed that it is abominable to ride al-jallalah without liner or blanket due to the possibility of direct contact with the animal's sweat'. The stench of faeces manifests in the sweat and taste of the animals that feed on it.

While Sunan An-Nasaie has two hadith in the Book of ad-Dahaya (sacrifices) on the prohibition of eating animals that eat faeces, one with particular mention of a domesticated donkey and the prohibition of eating its meat and riding it. Another narration is by Ibn Abbas, "The Messenger of Allah PBUH forbade animals that had been taken as targets, the milk of aljallalah, and drinking directly from water skins", (An-Nasaie, 1986). A similar hadith is found in Jami 'at-Tirmidhi in the Book on Food, (At-Tirmidhi, 2000). The mainstay in the scholarly discourse surrounding al-jallalah is the ruling on the consumption of the meat of al-jallalah and its derivatives, and the period of quarantine.

The fuqaha (Islamic jurists) differ over the ruling of consuming al-jallalah. The opinions held by the Imams (leaders) of the schools of jurisprudence are mubah (permissible), makruh (reprehensible), and haram (unlawful). Imam Ahmad bin Hanbal viewed consuming al-jallalah as utterly haram as indicated in the word naha (forbade) in the hadith of Ibn Umar: "The Messenger of Allah PBUH prohibited eating the animal which feeds on filth or drinks its milk" (Al-Mubarakfuri, 1979; Jamaludin et al., 2014). Most of the scholars from the Hanbali school of Islamic jurisprudence coincide with this opinion, 'their argument was that animals would become unclean by eating unclean things. Thus, the ruling on eating unclean things is determined as haram or forbidden', (Hamdan et al., 2017).

Imam Abu Hanifah and Imam Shafi'i share the same view, which is makruh. Imam Abu Hanifah further specified it as makruh tanzihi which means something detestable, but it leans towards permissible. He also proposed that consuming al-jallalah would be permissible if the aljallalah animal were quarantined first, (Iqbal et al., 2019; Jamaludin et al., 2014). It is most of the Islamic scholars' opinion that the consumption of al-jallalah is makruh and not haram. Hamdan et al. (2017) reported that the reason is that the faeces pass through the animal's digestive tract, and it does not get absorbed into its flesh, yet it can affect its taste and smell. Hence, the prohibition is subject to the change in the taste, smell and colour of the meat. If an animal consumes faeces, but there is no noticeable difference in the meat from a normal one, its consumption would be mubah (permissible).

The third opinion mubah is held by al-Layth, (Jamaludin et al., 2014), Malik and Al-Hasan Al-Basri, (Hamdan et al., 2017; Saidin et al., 2017). According to Hamdan et al. (2017), 'They established the ruling (qiyas) on al-jallalah animals based on birds that eat unclean things, liquor drinkers and infidels who eat pork and other unclean foods'. Their bodies and flesh will not be rendered filthy literally and physically, but rather figuratively.

\subsection{Feeding Animals from non-Halal Foods}

The issue of feeding animals with food that is haram because it contains al-najasah (filth) has been discussed extensively by classical Islamic scholars. There are two classifications of animals, according to fuqaha - consumable animals and non-consumable animals. There is no harm in feeding non-halal food (i.e. non-halal animal feed) to non-consumable animals. This matter has been proclaimed by fuqaha, as mentioned by al-Kasani (1986):

"According to Imam Abu Hanifah, flour that has been made into dough with water containing al-najasah shall not be eaten, if it is not eaten, what they should be made 
of it? Our shuyookh (teachers) said: Feed it to the dogs; because what has been tainted with al-najasah is not permissible for consumption, but to benefit from it is allowed."

This is the opinion of the majority of fuqaha, and it pertains to non-consumable animals like cats and dogs. Fuqaha dispute over the permissibility of feeding al-najasah or al-najasah containing feed to consumable animals like cow and sheep. There are four opinions pertaining to this matter highlighted as follows:

i) feeding consumable animals al-najasah is allowed, and this is the opinion of Imam Ahmad, (Al-Mardawi, 2003);

ii) it is makruh to feed with purely al-najasah if it is mixed with water then it becomes permissible, and this is the opinion of the Shafi'i mazhab, (An-Nawawi, 2008);

iii) feeding al-najasah is allowed if the animal will not be slaughtered, according to one narration from Ahmad, (Al-Mardawi, 2003; Ibn Qudamah, 1968);

iv) it is not permitted at all, based on an opinion in the Hanbali mazhab, (Al-Mardawi, 2003).

The strongest of the four is the opinion which allows it, but the al-jallalah animal must be quarantined if it mostly eats al-najasah, until its flesh no longer emits foul stench. The opinion on the permissibility of feeding animals -consumable or non-consumable- with al-najasah is supported by hadith of Ibn Umar, (Al-Bukhari, 2002):

"The people landed at the land of Thamud called Al-Hijr along with Allah's Messenger, and they took water from its well for drinking and kneading the dough with it. (When Allah's Messenger heard about it) he ordered them to pour out the water they had taken from its wells and feed the camels with the dough."

The indicator (wajhu al-dilalah) in the above hadith is that the Prophet PBUH ordered to feed the camels with the dough which was forbidden to be eaten. Therefore, all things forbidden to be eaten, by analogy (qiyas), follows this rule. If it is permissible to feed consumable animals, something unlawful, feeding it to animals that shall not be consumed would also be permissible, because it will not be eaten anyway. Since feeding consumable animals with filth is allowed, feeding it non-halal meat is also allowed, despite being unlawful for human consumption. Furthermore, non-halal meat is only unlawful for humans; it remains lawful for other creatures. The fatwa issuing councils of Malaysia, Indonesia and Brunei, however, differ from this opinion. The $73^{\text {rd }}$ National Muzakarah Council on Islamic Religious Affairs Committee (MJFK) which convened on $4^{\text {th }}-6^{\text {th }}$ April 2006 issued the fatwa that if fish is deliberately fed with haram or reared in water containing filth, it shall be classified as al-jallalah, and the consumption of that fish is haram, (Jamaludin et al., 2014).

In a decision by other council members, albeit ungazetted, ruled out the practice of feeding fish with dead chickens as haram. The states of Kelantan and Selangor have issued a fatwa in a similar vein, it 'disallowed feeding aquacultured fish with feed derived from najs (filth) and animal waste as a step of saddu zarai ' (preventing vices)', (Iqbal et al., 2019). The fatwa issued by the Indonesian Ulema Council (MUI) prohibited the trading and production of animal feed that contain swine elements and/or other non-halal elements. Similarly, Darulifta' Brunei Darussalam concurred with the decision to disallow halal feeding animals for consumption with 
najs (filth) and deemed the practice makruh,. (Tarmizi, 2018). In that case, would feeding animals with BSF larvae be considered similar to feeding the animals with non-halal food/feed? The following section attempts to explore this issue in greater detail.

\subsection{Proposed Reasons for the Compromise in Halal Status of Meat Products}

There are two proposed reasons why the animal's halal status might be nullified by the black soldier fly larvae. Firstly, the notion of consumable animals eating al-jallalah. The black soldier fly larva itself would, by definition, be categorised as al-jallalah because it is a coprophagous insect. In this case, the consumable animal would be chicken or fish feeding on black soldier fly larvae. Classification of al-jallalah in Islamic jurisprudence is when an animal eats filth and impurities consistently over a sustained period, and al-najasah makes up most of its diet. The animals in poultry farming and aquaculture are not fed biowaste consisting of manure and faeces themselves. Instead, they are fed with the larvae that feed on those wastes. There is no direct correlation between these animals and the al-najasah (filth).

However, considering the fact that the al-jallalah insect in itself is impure, technically the animal is fed something impure. To draw on the opinion of the majority of Islamic scholars, 'the legal ruling of haram or makruh of the al-jallalah is due to the 'illah', (Saidin et al., 2017). As a rule of thumb, the 'illah (effective or operative reason) is the deciding factor in the status of the animals fed with black soldier fly larvae. If the negative effects of eating something impure, i.e. the bad smell and taste, do not manifest in the animals, then it is safe to conclude that the pureness of the animal remains intact.

The second proposed reason is regarding consumable animals eating the carcass. Mounting evidence is pointing towards the practice of feeding livestock with carcasses or traces of it by the farming industry, which has resulted in meat and fish products unsuitable for Muslims to consume. One such example is the bovine spongiform encephalopathy (BSE), also known as the mad cow disease epidemic in the United Kingdom, which began in 1986. It was a result of feeding 'the rendered carcasses of livestock (including sheep) to ruminants and other animals as a protein-rich nutritional supplement', (Brown et al., 2001). The 'mad cow disease' threatened the spread of the virus from animals to humans through the consumption of beef products contaminated by BSE. As history would tell, it triggered an outbreak of human Creutzfeldt-Jakob disease (Brown et al., 2001).

From an Islamic standpoint, there is more than one offence in the malpractice of feeding animals with the carcass. The first of which is feeding consumable animals something that is deemed impure in the Qur'an: "Say, I do not find within that which was revealed to me [anything] forbidden to one who would eat it unless it is a dead animal or blood spilt out or the flesh of swine - for indeed, it is impure..." (Qur'an 6:145). Another offence is feeding animals with food unintended for it, which would be maltreatment as it harmed the animal by introducing diseases into its body. Having said all this, whether or not BSF larvae could be considered as a carcass in the same context of divine sanction against carrion is debatable.

Domesticated chickens naturally forage for food like grains, vegetation and invertebrates, that includes fly larvae. Despite the coprophagic nature of chickens, (Tsubokura, 1997), they are halal for consumption as unanimously agreed upon by Islamic scholars based on a hadith: "Abu Musa was presented with a dish containing chicken. Among the people, there was sitting a redfaced man who did not come near the food. Abu Musa said (to him), 'Come on (and eat), for I 
have seen Allah's Messenger PBUH eating of it (i.e. chicken)'”, (Al-Bukhari, 2002; Muslim, 1998).

\subsection{Quarantine: Theory and Practice}

Al-jallalah animals which have been contaminated by najasah can be returned to a state of purity that is valid for slaughtering and consumption. The animal must be quarantined, a process of eliminating najasah from its dietary intake and feeding it with clean and pure sources of food. The process is termed as al-habs in fiqh literature, and it means containment. Al-habs serves as a purification mechanism that changes the nature of al-jallalah at the biological level through the process known as istihalah (transformation or conversion). It takes place when the physical manifestations of impurities in its flesh, eggs, milk, smell and sweat are no longer present in the animal, thereby becoming mubah (permissible) for consumption. The fuqaha have applied the principle 'إذا زالت العلة زال الحكيم' in adopting quarantine as a viable method of reversing the state of impurity in animals. The legal maxim implies that if the ruling applies because of an illah (reason), it ceases to apply when that 'illah disappears. In this case, the 'illah would be the smell of the al-jallalah animal, when it goes away, so does the prohibition or karahah (undesirability). Moreover, the companion Ibn Umar reportedly kept a al-jallalah chicken for three days before consuming it, (Az-Zuhaili, 1984), and this lends support to the legitimacy of quarantine as a practice.

The period for quarantine of al-jallalah is not specified and unbinding. The Hanafi and Shafi'i mazhabs and Ibn Hazm (an Andalusian Muslim polymath, d. $1064 \mathrm{CE}$ ) adhere to this principle as an accepted method to determine the status of al-jallalah. Imam Abu Hanifah did not stipulate a quarantine period; however, some Hanafi scholars estimated three days of quarantine for chicken, four days for goat and sheep, and ten days for camel and cow (At-Tahtawi, 1997). In contrast, the Shafi'i mazhab suggested a forty-day quarantine for a she-camel, thirty days for the cow, seven days for sheep and three days for chicken. Ultimately, the al-najasah should be removed regardless of these recommendations. If traces of al-najasah disappear in a shorter period than that recommended, the animal would no longer be makruh. An-Nawawi (1991) affirmed that the status is not determined by a definite measure, preferably based on the norm or assumption for when the smell would have disappeared. The number of days for each type of animal is meant to serve as a guideline for the average Muslim to consider, the bottom line is that larger-sized animals take a longer time to undergo al-istihalah.

\subsection{Fatwa on the Use of BSF as Animal Feed}

BSF larvae only entered the feed industry scene in the mid-twentieth century, and it still did not do so much as to change the status quo of formulated compound feed. It is a relatively new feed ingredient and did not create that much buzz among consumers and is only of interest to few parties like feed millers, farmers, manufacturers, and feed traders. Therefore, its status as halal and/or toyyib feed replacement is not widely discussed. There is only one fatwa issuing body in Southeast Asia that has addressed this issue, albeit indirectly. The Fatwa Commission of Indonesian Ulema Council published the ruling on humans consuming, cultivating, and using BSF larvae in 2019. The council concluded that BSF larvae consumption is haram because it is a type of hasyarat (insect). All hasyarat is prohibited for consumption based on the majority of Hanafi, Shafi'i and Hanbali scholars, except for grasshopper. Grasshoppers are a dead type of meat that Prophet Muhammad PBUH permitted for consumption, the other being fish. This 
hadith is recorded in Sunan Ibn Majah, Musnad Ahmad and Sunan Ad-Daruqutni (Majelis Ulema Indonesia [MUI], 2019).

The council also declared that cultivating BSF larvae to capitalise on its beneficial properties, like animal feed, is mubah (permissible). It did not cite any text from Qur'anic and hadith scriptures, nor legal principles and opinion of jurists to arrive at that ruling. Although it is surmised from the text that the committee found the BSF larvae to be generally useful to the people, there is no harm to benefit from it but not consuming it for the reasons mentioned.

The Permanent Committee for Scholarly Research and Ifta' based in Saudi Arabia released a fatwa in response to an inquiry about feeding chickens with milled meat animals, including pigs. The committee declared that there is a difference in opinion among scholars concerning eating its meat and eggs. Imam Malik and a few other scholars maintained that eating its meat and egg is mubah because the al-najasah would have been purified through al-istihalah. Others like Ath-Thawri, As-Shafi'i and Ahmad suggested that meat, eggs, and milk consumption are prohibited until it is fed with clean food for three days or more. Qiyas (analogy) can be employed based on this account for BSF larvae. One of the ways it is administered as animal feed is by drying, milling and adding it to formulated feed.

To further strengthen the case for BSF larvae as animal feed, the distinguished Islamic scholar Salih bin Uthaymeen (2005) viewed that even spilt-out blood (damm masfuh) that has been incorporated into poultry feed for nutrition purposes is not forbidden nor disliked. In determining the status of al-jallalah, the clean to unclean ratio in the food intake of the animal is considered. If clean and pure food sources make up the larger part of its diet, then the animal is not al-jallalah. Spilt-out blood is a greater degree of al-najasah than the BSF larvae as it was explicitly mentioned in the Quran alongside carrion and flesh of swine. Then it is assumed that the use of BSF in or as animal feed is of lesser significance.

Al-Qazzaz et al. (2016) noted that the odour of eggs was not affected by dietary treatments with BSF larvae. An experiment studying the effects of total replacement of dietary fish meal with BSF larvae was conducted, and the results indicated that it does not impair physical, chemical or volatile composition of farmed Atlantic salmon (Salmo salar L.). There is virtually no difference in the salmon fillets' taste and odour based on consumer tests (Bruni et al., 2020). The makruh or haram ruling on al-jallalah shall not apply because the 'illah is not present based on these accounts. As long as the illah is not present, then the ruling is permissible. This

conforms with the legal maxim 'الأصل في الأشياء الإباحة', meaning the natural state of things is mubah (permissible).

\section{CONCLUSION}

Guided by the maxims of Islamic jurisprudence, the current study has engendered the confirmation of the permissibility of using BSF larvae as animal feed and consuming animals fed with the larvae regardless of whether its dietary intake consists of clean or unclean wastes. However, as far as hygiene and public health are concerned, stakeholders may want to avoid faeces in the feed supply chain, i.e. faeces as biowaste substrate in the process of engineering BSF life-cycle. The most straightforward initial approach to mitigate this concern would be to utilise BSF larvae reared on clean waste, in controlled farming environments to reduce the potential associated risks such as heavy metal uptake and potentially pathogenic microorganisms. Farmers and manufacturers are suggested to use substrates that are fish-based or plant-based or 
wastes that are clean such as pre-consumer vegetable matter. The involvement of competent halal authority in the feed supply chain is equally important to ensure those larvae are only fed halal sources of plant-based or fish-based diet. Reflecting upon the study's limitations, the researchers are extending the implications to research in regard to Muslim consumer perception towards BSF as animal feed in light of the considerations of 'urf (custom tradition).

As of this moment, it is hard to gauge the perception and acceptance of Muslim consumers towards BSF larvae as animal feed. Consumers know little about livestock feed in general, and thus are mostly unaware of the potential use of BSF larvae. Consumer perception surveys need to be carried out to learn about consumers' attitude towards eating larvae-fed animals. Furthermore, information on the food safety risks of consuming BSF larvae-fed animals is scanty. Its clinical effect in humans still requires further research and understanding. This way, it can be determined if there are adverse effects, healthful benefits, or lack of consuming those meat products and subsequent syari'ah ruling can be applied accordingly.

\section{REFERENCES}

[1] Abu Dawud, A. S. (2009). Sunan Abi Dawud. Cairo: Dar ar-Risalah al-Alamiyah.

[2] Al-Bukhari, M. I. (2002). Sahih Al-Bukhari. Beirut: Dar Tauq an-Najah.

[3] Al-Kasani, A. (1986). Badai' As-sanai'. Lebanon: Dar Al-Kitab Al-Ilmiyah.

[4] Al-Mardawi, A. (2003). Al-Furu' wa Tasheeh Al-Furu'. Beirut: Muassasah Risalah.

[5] Al-Mubarakfuri, A. A. A. M. (1979). Tuhfah al-Ahwadhi bi Syarh Jami` al-Tirmidhi. Beirut: Dar al-Fikr.

[6] Al-Qazzaz, M. F., Ismail, D., Akit, H., \& Idris, L. H. (2016). Effect of using insect larvae meal as a complete protein source on quality. Revista Brasileira de Zootecnia, 518-523.

[7] An-Nasaie, A. S. (1986). Sunan An-Nasaie. Aleppo: Maktab al-Matbuat al-Islamiyah.

[8] An-Nawawi, M. Y. (1991). Raudhotu At-Talibin wa Umdatul Muftin. Oman: Maktab AlIslami.

[9] An-Nawawi, Y. (2008). Al-Majmu' Sharh Al-Muhazzab. Damascus: Maktabah Irsyad.

[10] At-Tahtawi, A. (1997). Hashiah At-Tahtawi. Beirut: Dar Al-Kitab Al-Ilmiah.

[11] At-Tirmidhi, A. I. (2000). Jami' At-Tirmidhi. Saudi Arabia: Saudi Ministry of Islamic Affairs, Dawah and Guidance.

[12] Az-Zuhaili, W. (1984). Al-Fiqh Al-Islami wa Adillatuhu. Damascus: Dar Al-Fikr.

[13] Barragan-Fonseca, K. B., Dicke, M., \& van Loon, J. J. (2017). Nutritional value of the BSF (Hermetia illucens L.) and its suitability as animal feed - a review. Journal of Insects as Food and Feed, 105-120.

[14] Barroso, F. G., Sanchez-Muros, M. J., Segura, M., Morote, E., Torres, A., Ramos, R., \& Guil, J. L. (n.d.). Insects as food: Enrichment of larvae of Hermetia illucens with omega 3 fatty acids by means of dietary.

[15] Brown, P., Will, R. G., Bradley, R., Asher, D. M., \& Detwiler, L. (2001). Bovine Spongiform Encephalopathy and Variant Creutzfeldt-Jakob Disease: Background, Evolution and Current Concerns. Emerging Infectious Diseases, 6-16.

[16] Bruni, L., Belghit, I., Lock, E.-J., Secci, G., Taiti, C., \& Parisi, G. (2020). Total replacement of dietary fish meal with black soldier fly (Hermetia illucens) larvae does not impair physical, chemical or volatile compostition of farmed Atlantic salmon (Salmo salar L.). J Sci Food Agric, 1038-1047. 
[17] Čičková, H., Newton, G. L., Lacy, R. C., \& Kozanek, M. (2015). The use of fly larvae for organic waste treatment. Waste Management, 68-80.

[18] Dortmans, B., Diener, S., Verstappen, B., \& Zubrugg, C. (2017). Black Soldier Fly Processing A Step-by-step Guide. Dübendorf: Eawag - Swiss Federal Institute of Aquatic Science and Technology.

[19] Gomez Candela, C., Bermejo Lopez, L. M., \& Loria Kohen, V. (2011). Importance of balanced omega 6 omega 3 ratio for the maintenace of health: Nutritional recommendations. Nutricion Hospitalaria, 323-329.

[20] Hamdan, M. N., Post, M. J., Ramli, M. A., \& Mustafa, A. R. (2017). Cultured Meat in Islamic Perspetive. J Relig Health, 1-14.

[21] Hirakawa, H. (2001). Coprophagy in leporids and other mammalian herbivores. Mammal Rev, 61-80.

[22] Ibn Qudamah. (1968). Al-Mughni. Cairo: Maktabah Qahirah.

[23] Ibn Uthaymeen, S. (2005). Sharh Riyadussalihin. Riyadh: Madar Al-Watan Lilnashri.

[24] Iqbal, A., Qudoos, A., Cetingul, I. S., \& Shah, S. R. (2019). Looking at some animal feeds with respect to halal concept. Journal of Animal Research, 46-53.

[25] Iqbal, N. K. (2015). From Permissible to Wholesome: Situating Halāl Organic Farms within the Sustainability Discourse. Islamic Sciences, 49-56. Retrieved from EBSCOhost Research Database.

[26] Jamaludin, M. A., Ramli, M. A., \& Rahman, S. A. (2014). Al-jallalah: Konsep dan Fatwa Semasa di Malaysia. Jurnal Infad, 31-44.

[27] Majelis Ulema Indonesia. (2019). Fatwa MUI tentang Larva Lalat Tentara Hitam (Hermetia Illucens / Black Soldier Fly). Retrieved from Majelis Ulema Indonesia: http://www.halalmui.org/images/stories/Fatwa\%20Larva\%20Lalat\%20Tentara\%20Hitam $\% 20($ INA).pdf

[28] Muslim, i. A.-H. (1998). Sahih Muslim. Cairo: As-Salam.

[29] Omar, E. N., Jaafar, H. S., \& Osman, M. R. (2013). Assessing Halalan-Toyyiban Food Supply Chain in the Poultry Industry. International Halal Conference (p. 4). Shah Alam: Elsevier Ltd. Selection.

[30] Saidin, N., Rahman, F. A., \& Abdullah, N. (2017). Animal Feed: Halal Perspective. International Conference on Humanities, Social Sciences and Education, (pp. 69-74). London.

[31] Saima, M. A., Khan, M. Z., Anjum, M. I., Ahmed, S., Rizwan, M., \& Ijaz, M. (2008). Investigation on the availability of amino acids from different animal protein sources in golden cockerels. Journal of Animal and Plant Sciences, 53-56.

[32] Schremmer, F. (1986). Die polymetabole Larval-Entwicklung der Waffenfliegenart Hermetia illucens. Ein Beitrag zur Metamorphose der Stratiomyidae. Ann. des Naturhistorischen Museums Wien, 405-429.

[33] Tarmizi, L. (8 June, 2018). Irsyad Al-Fatwa Series 229a: The Ruling of Feeding Poultry With Doubtful Animal Feed. Retrieved from Official Website Mufti of Federal Territory: https://www.muftiwp.gov.my/en/artikel/irsyad-fatwa/irsyad-fatwa-umum-cat/2454irsyad-al-fatwa-series-229a-the-ruling-of-feeding-poultry-with-doubtful-animal-feed

[34] Tsubokura, K., Berndtson, E., Bogstedt, A., Kaijser, B., Kim, M., Ozeki, M., \& Hammarstom, L. (1997). Oral Administration of Antibodies as Prophylaxis and Therapy in Campylobacter Jejuni-infected Chickens. Clin Exp Immunol, 451-455. 
[35] Wang, Y. S., \& Shelomi, M. (2017). Review of BSF (Hermetia illucens) as animal feed and human food. Foods, 91.

[36] Wood, T. (6 November, 2017). Fly Larvae Are Good for Chickens, but How Do They Affect Your Organic Eggs? Retrieved from UCDAVIS: https://www.ucdavis.edu/news/fly-larvae-are-good-chickens-how-do-they-affect-yourorganic-eggs/ 